\title{
The Study of Regulations Governing Shipping Bill of Lading in Iran Laws and International Trade Documents
}

\author{
Seyedeh Koyestan Sharify ${ }^{1} \&$ Ali Mohammad Mokarrami ${ }^{2}$ \\ ${ }^{1}$ Department of Law, UAE Branch, Islamic Azad University, Dubai, UAE \\ ${ }^{2}$ University of Judicial Sciences, Tehran, Iran \\ Correspondence: Seyedeh Koyestan Sharify, Department of Law, UAE Branch, Islamic Azad University, Dubai, \\ UAE. E-mail: Seyedeh.sharify@gmail.com
}

\author{
Received: July 12, 2016 Accepted: August 18, 2016 Online Published: September 29, 2016 \\ doi:10.5539/jpl.v9n8p44 URL: http://dx.doi.org/10.5539/jpl.v9n8p44
}

\begin{abstract}
The present study deals with review of regulations governing shipping bill of lading in Iran laws and international trade documents through descriptive analysis. In this paper, it is tried to study the concepts of maritime transport contract, legal concept of vessel, shipping bill of lading and its components, the content of shipping bill of lading and its proofing aspects in international conventions and Iran law. The research findings indicate that shipping bill of lading is considered one of the valid documents in international trade and in accordance with the common trade, judicial procedures and the maritime code of Iran and Hamburg convention is considered as a common trade document. In Rotterdam convention, the capability of transferring written and electronic transport record and their transferring procedure as used in trade documents has been mentioned. The value and credit of shipping bill of ladings of goods embarked on deck or clean bill of lading in international trade made such bill of ladings be supported by trade code in international trade and conventions and local regulations of countries such that the transportation agents are prohibited from the right to prove negative of some contents of this document against the holder in good faith of shipping bill of lading.
\end{abstract}

Keywords: shipping bill of lading, maritime transport, Iranian Maritime Code, Hamburg convention, Rotterdam convention

\section{Introduction}

Industrial revolution in mid- $18^{\text {th }}$ century lead to increasing expansion of maritime transportation and shipping bill of lading that emerged in $14^{\text {th }}$ century in legal realm has evolved in 600 -year period and its dimensions, specifications and its governing legal laws have been defined or identified. On the other hand, increasing expansion of maritime transportation and the significance of this document in international transactions and trade and the expansion of laws governing it in international aspect made a convention passed as "International convention on integration of some laws on shipping bill of lading" known as "Hague Convention" or Brussels. After approval of this convention, its deficiencies soon became clear and attempts to remove these deficiencies lead to passing Visby Protocol in 1965 and in 1968, the revisions approved within Visby protocol were directly included in Hague convention and passed by in some countries as "Visby-Hague Rules". Again, in 1979, another amending protocol related to Hague convention was passed as "SDR" protocol; yet, none was generally adopted by the countries.

On the other hand, "United Nations Conference on Trade" (UNCTAD) that had the responsibility of developing regulations on maritime transportation decided to prepare a convention independent of Hague convention, its protocols and Visby-Hague regulations; to this end, in 1978, Hamburg convention was passed as "International maritime transportation convention" and put in to effect in 1992 with signature of 20 countries. Nonetheless, in so far as most ship-owning countries did not join Hamburg convention and also due to inefficiency of this convention, in one hand, and significant growth of linear transportation and popularity of "door-to-door" contracts and spread of mechanized transportation of good by container, in one hand; and due to necessity of equal support of developing countries (that are mainly owners of good) against developed countries (who are mainly vessel owners) and nonconformity of old laws in Hague convention, its attached protocols and Visby-Hague laws with the modern maritime transportation needs, United Nations Commission on International Trade Law (UNCITRAL) considered development of an integrative convention in its agenda and Rotterdam convention was finally approved by general 
assembly of United Nations after adjustments and modification and in 2009, after being signed by 20 countries in membership of united nations entered into force in the realm of international law as binding convention.

Iran considered regulations on maritime transportation in maritime code in 1964 (in articles 52 to 68) and in February 3, 1965 joined Hague convention as "Law on Accession of the Imperial Iranian Government to Seven International Maritime Law Contracts". Nevertheless, despite the fact that at that time, two protocols were attached to Hague convention and Visby-Hague regulations (that is amended version of Hague convention) in 1968 and Hamburg convention was passed in 1378 and Rotterdam convention in 2008, during this time, no action has been table to update the maritime transportation laws and regulation and despite expectations, in new amendment in "Amended law of maritime code" approved in 2012, no article related to maritime transportation has been revised. In this paper, it is tried to review the concept of shipping bill of lading and its proofing aspect in international conventions by looking at Iran law.

\section{Concepts}

\subsection{Maritime Transport Contract (Maritime Shipping)}

"Transport contract is just the contract that is hold in accordance with shipping bill of lading or similar documents for shipment and for any shipping bill of lading or another document that is considered transport contract based on contract chartering between shipment agent and the holder of bill of lading or mentioned document from the time of issuance" ${ }^{1}$.

In this definition that is prepared and developed by adopting part $\mathrm{B}$, article 1 of international convention for coordination of some shipping bill of lading regulations passes on 16 August 1924, Brussels, some points should be considered: 1- transport contract is not hold unless in accordance with shipping bill of lading or similar documents. 2- by saying, "transport contract is just contract hold in accordance with shipping bill of lading or similar documents,... ", the legislator makes the existence of shipment conditioned on issuance of shipping bill of lading or similar documents (that will be discussed later). Thus, holding any contract between the consignor of product and the transportation agent without issuance of shipping bill of lading or similar documents is not considered transport contract ${ }^{2}$. 3- Maritime transport contract should be hold in accordance with shipping bill of lading. 4- Contract is hold for transport of goods. The legislator has emphasized transport of goods as the aim of holding contract and has emphasized on it. It seems that the main aim of good transfer in commercial shipping, lack of development of passenger transport and insignificance activities of marine passenger transport companies made legislative maritime transport companies neglect consideration of passenger transport; thus, limited maritime transport to shipment. 5- Shipment contract is used for any shipping bill of lading that is according to contract chartering between transport agent and holder of shipping bill of lading. According to paragraph 2, article 52 of maritime law, when a bill of lading is hold in accordance with contract chartering and relates the transport agent and holder of shipping bill of lading, this bill of lading will have the credit of contract of transportation. 6Documents similar to shipping bill of lading according to which contract chartering and contract of shipment is hold, "Similar documents" is an expression mentioned in marine law and in paragraph $b$, article 1 of Brussels international convention 1924 to coordinate some laws of shipping bill of lading. It is not clear that what the legislator mean by these expressions and we do not know that which documents they include.

Hamburg convention considers maritime transport contract the one through which the cargo is transferred from sea and a port to another port and if in this contract, part of path is dry land an part is sea, the contract will be considered maritime transport contract in part that transport is done through sea. Hamburg convention has expanded the scope of this transport contract more than Hague convention since according to this convention, all shipping bills of lading, "ownership documents" and spoken and written agreement for shipping cargoes are included by the regulations of Hamburg convention ${ }^{3}$. Moreover, according to article 18 of Hamburg convention, "when transport agent issues a document other than shipping bill of lading as, "the receipt of cargo that should be transported", such document will be the reason for holding maritime transport contract and cargo delivery by transporting agent as mentioned in document.

In maritime code, mostly "shipping bill of loading" and "transport contract" are frequently used and this use arouse this question that whether shipping bill of lading and transport contract are the same or they are detachable. If shipping bill of lading is part of transport contract, preliminary negotiations, announcement of shipping company,

\footnotetext{
${ }^{1}$ Paragraph 2, article 52 of Iran Maritime code

${ }^{2}$ Esna Ashari, Y. (1988). The responsibility of marine transport agent (MA thesis). Advisor: Morteza Najafi Asfah, p. 24.

${ }^{3}$ Moalemnia, A. (1999). The nature of shipping bill of lading and its role in maritime transport. MA thesis, University of Tehran (Qom Complex of High Education)
} 
business practice, transport request and proposed rental rates could be considered part of transport contract and affect the provisions of the shipping bill of lading.

General procedure in maritime transport is such that shipping bill of lading will be issued after lading; while in most cases, usually the agreements between parties happen before lading that might be contrary or opposite to content of bill of lading; thus, most jurists don't consider shipping bill of lading as transport contract and believe that shipping bill of lading is not in itself transport contract but indicative of transport contract ${ }^{4}$. In other words, according to this theory, transport contract is hold before issuance of shipping bill of lading; thus, if cargo is damaged before issuance of shipping bill of lading, the affected could claim against transport agent in accordance to transport contract ${ }^{5}$. However, in this condition, due to failure of issuance of shipping bill of lading, the affected should prove the transport contract relying on various reasons.

In Pyrene v. Scindia navigation Co (1954), the court claimed that Hague regulations determine the rights of parties at the time of lading even though shipping bill of lading is not issued ${ }^{6}$, the vote that is contrary to paragraph $\mathrm{b}$ of Article 1 of Hague Convention. "Lord Bramol" considers shipping bill of lading as the receipt of goods, the document that describes the condition of the goods upon delivery; moreover, transport contract is hold before issuance of shipping bill of lading ${ }^{7}$.

In Hamburg convention, according to paragraphs $d$ and $e$ and article 18, except shipping bill of lading, "other documents" could indicate transport contract and despite such document (that is not shipping bill of lading), the relation between parties would be subject to Hamburg convention. In other words, despite Hague convention that considers maritime transport contract conceivable just in content of shipping bill of lading and "document of ownership" and considers the relations between parties subject to Hague convention just in such conditions. In Hamburg convention, according to article 18, any document that is issued by the transport agent and indicates the receipt of good by the transport agent is considered "presumptive" on the existence of transport contract.

This is while in article 14 of Hamburg convention, the transport agent is allowed to issue just shipping bill of lading and no other document and according to paragraph $\mathrm{b}$ of article 15, two other documents could be issued by the transport agent, one is "maritime bill of loading" and the other, "ownership document"; the latter will be explained in this paper and Hamburg convention intends, "A received-for-shipment bill of ladin ${ }^{\mathrm{g}}{ }^{8}$ " by saying shipping bill of lading in this paragraph. Thus, it seems that the expression, "other documents expect shipping bill of lading" used in article 18 of Hamburg convention should be interpreted beside paragraph 2 of article 14 and article 18 could not be the permit for transport agent to issue any desired document and article 18 intends limited and occasional items that are in some way not executed according to article 14 or paragraph 2 of article 15 . As example, if due to time constraint or mutual trust of parties, only transport contract is hold or no contract is hold at all, article 18 will be applicable. Thus, concerning the above-mentioned items, it could be said that in Hamburg convention, shipping bill of lading has preserved its authority as the basic document of maritime transportation.

In Rotterdam convention that is tried to have more complete recall and precision than previous conventions, the authors have not used the well-known expression "bill of lading", instead, they have used two new expressions, "written transport document" and "electronic transport record ${ }^{10 "}$. In this convention, in paragraph 1, article 1, maritime transport contract has been defined and in paragraphs 14 and 18 of this article, "written transport

\footnotetext{
${ }^{4}$ Omid, H. (1973). Maritime Code, $1^{\text {st }}$ Vol., Tehran, Higher School of Insurance, p. 208.

${ }^{5}$ Ibid. p. 53

${ }^{6}$ Ibid. p. 54

${ }^{7}$ Raoul Colinvaux, Carver's Carriage by Seag Vol 1, London Steven \& Sones, 1973. p.

${ }^{8}$ A received-for-shipment bill of lading is on contrary to "on board bill of lading" which is usually used in FOB. In these cases, according to FOB contract, the obligation of seller ends by delivery of cargo in port and according to international trade norm, the seller request for issuance of a received-for-shipment bill of lading from transport agent. The latter shipping bill of lading confirms that the cargo is on board and shipment has started. However, in former, it is conformed that cargo is delivered to transport agent and stored in port of loading but not loaded on ship

${ }^{9}$ Abdullahi in "Rotterdam convention" ( $1^{\text {st }}$ ed, Tehran. port of special areas PMO, 2010) and Kardan (in paper published in journal of law, faculty of law and political sciences, No. 1, pp. 255-275) have used "transport document" for "written transport document" while, as used beside "electronic transport record" for better distinction of these two documents that is one electronic and one printed, the use of "written transport document" is more comprehensive.

${ }^{10}$ Yari, M. (2011) in his paper, "The review of Rotterdam Convention" in international Legal journal, Year 28, No. 45, pp. 105-138 and in his Master's thesis, "The review of Hague 1924 regulations concerning international maritime transport and Rotterdam Convention in 2008 and its probable effect on Iran maritime code", electronic transport record is called, "electronic transport background" that seems not appropriate since "electronic transport record" is a dynamic document while "background" indicates past affairs which is not good translation at least in Rotterdam convention.
} 
contract" and "electronic transport contract" are defined. The definition of maritime transport contract in Rotterdam convention, is almost the same as written in Hamburg convention with this difference that in paragraph 6, article 1 of Hamburg convention, "Port-to-port" displacement is mentioned; while, in Rotterdam convention, "place-to-place" is used and it seems that the use of this expression concerning Rotterdam convention that tries to include previous and future non-maritime transports is justifiable; in this regard, there is some difference between lading "port" and "place" of cargo receipt and delivery in paragraph 1, article 5 of Rotterdam convention ${ }^{11}$.

In Rotterdam convention, according to paragraphs $14 \mathrm{~b}$ of article 1 and paragraph $18 \mathrm{~b}$ and 23 of article 1 , "written transport document" and "electronic transport record" have appeared in accordance with transport contract and also include transport contract ${ }^{12}$. However, un article 35 of this convention, the parties are allowed to give up issuance of transport documents; thus, it could be said that in Rotterdam convention, the same as Hamburg convention, transport contract is not just manifested in transport document and even in case of failure to issue transport document, transport contract might exist and in confirming this procedure, in article 45 of Rotterdam convention, the possibility of goods delivery has been predicted without issuance of any transport document. In this way, it could be claimed that shipping bill of lading and transport document contain transport contract and evidence of the existence of this contract and the best reason for proving transport contract and the terms between parties concerning carriage and shipping of goods and its terms and conditions; however, contract of shipping is not limited to transport document.

In Hague convention, "ownership document" is mentioned beside "shipping bill of lading". Based on definition in Black's law dictionary ${ }^{13}$, "document of title"14 includes a written description, identification, or declaration of goods authorizing the holder to receive, hold, and dispose of the document and the goods it covers. Documents of title, such as bills of lading, warehouse receipt, and delivery orders, are generally governed by Article 7 of the Uniform Commercial Code (UUC).

In Hamburg convention, just in one case in paragraph 2 of article 15, expression "document of title" has been used and in paragraphs $d$ and $e$ of article 2, "Other document" has been used beside shipping bill of lading and it seems that this expression is more comprehensive and general than document of title. In accordance with paragraphs $d$ and e of article 2 of Hamburg convention, other documents other than shipping bill of lading could indicate the transport document and such documents are subject to Hamburg convention. Nonetheless, it seems that in business practice, other document means document o title.

\subsection{Shipping Bill of Lading}

\subsubsection{Definition of Bill of Lading}

Shipping bill of lading is a document containing full specification of that cargo signed by the commander of vessel or the one appointed by him for this purpose who commits to deliver the cargo through the vessel to consignee in destination. Shipping bill of lading or similar documents means the receipt of that cargo ${ }^{15}$. In accordance to paragraph 7, article 53 of Iran maritime code, bill of lading is a document that the commander of vessel or his representative issues and includes the specification of loaded cargo. Thus, bill of lading is a document that the commander of vessel or his representative gives to consignor or his representative as receipt of cargo. Even with contract of chartering, bill of lading should be issued since as we will see later, bill of lading is to prove the act of delegating the right of exploitation of vessel through chartering; while, bill of lading is to prove the cargo. Bill of lading should be reviewed in respect of the terms and content and its probative value and its form.

In Hague convention, neither shipping bill of lading nor contract of transport is defined and just in paragraph $b$ of article 1, only the relation between contract of transport and shipping bill of lading is explained. In Iran maritime code, just in article 61, shipping bill of lading is likened to check. In Hamburg convention in paragraph 7, article 1, bill of lading is defined as a document indicating transport contract and delivery of goods to transport agent or its loading on ship and by which the transport agent commits to deliver goods upon receipt of shipping bill of lading.

\footnotetext{
${ }^{11}$ Yari, M. (2012). "A review of Hague 1924 regulations on international maritime transport and Rotterdom 2008 convention and its probable effect on Iran maritime code". MA thesis, Shahid Beheshti University. P. 18

12 - Yvonne Baatz, Charles Debattista, Filippo Lorenzon, Andrew Serdy, Hilton Staniland and Michael Tsimplis, The Rotterdam Rules (A Practical Annotation), London, informa, 2009, p 6

${ }^{13}$ Black's Law Dictionary, Editor Brayan A.Garner (editor in chief), 9Th Edition.2009

${ }^{14}$ Translation part of Iran Claims Tribunal (Hague), Encyclopedia of Legal Terms (English to Persian), fifth ed., Dad Afarin (2010), p. 24

${ }^{15}$ Paragraph 7 of article 52, Iran Maritime code; bill of lading is defined as follow in France Code: Le connaissement (Bill of lading ) est un document de transport signe par le transporteur (on song agent) ou le capitaine du navire carge (ou son agent) Le connaissement est un papier-valeur .II confirme la prise en charge de la merchandise pour le transport ou sa mise a bord et les conditions du transport .see :http:/ fr.wikipedea.org/wiki/connaissement.
} 
This definition is indeed based on effects of shipping bill of lading and has not directly defined shipping bill of lading. According to definition in Black's Law Dictionary, shipping bill of lading ${ }^{16}$ is a document showing the receipt of cargo by the transport agent, the existence of transport contract for that cargo and ownership document.

In Rotterdam convention, "written transport document" and "electronic transport record", in paragraphs 14 and 18 of article 1, are documents issued based on transport contract and indicate a. receipt of cargo and b. transport contract. This definition is the one in Hamburg convention of shipping bill of lading and concerning this subject and commercial description of these documents in Rotterdam convention, it could be concluded that "written transport document" and "electronic transport record" are naturally synonym to shipping bill of lading; however, in terms of the scope, due to not being tied to a special name or title, this expression includes a wide range and covers shipping bill of lading and else and shipping bill of lading is a subset of transport documents ${ }^{17}$.

In other words, the mention of transport document in Rotterdam convention is the same as article 10 of Iran civil code in support of the principle of freedom of contracts and spread of open contract and the same as article 10 of Iran civil code, it isn't denial of specific contract. This doesn't mean denial of the expression "shipping bill of lading" and its credit and prohibition of its use in transport contracts subject to Rotterdam convention and it could not be said that Rotterdam convention has ended the shipping bill of lading.

\subsubsection{Types of Shipping Bill of Lading}

\subsubsection{Clean Bill of Lading}

"Clean bill of lading"18 refers to the one in which the declared explanations by the consignor concerning the appearance of cargo, packaging and its weight and volume conform with observations and approvals of vessel commander and there is no controversy on the declared items by the consignor by the commander on $\mathrm{B} / \mathrm{L}^{19}$.

According to English judges, "clean bill of lading is the one without any (negative) terms and conditions concerning the appearance or packaging of goods" ${ }^{20}$ or "without no imposed condition or note that clearly declare incomplete status of goods or packing"21

Clean $\mathrm{B} / \mathrm{L}$ is very significant in international trade and the tradesmen do their business and buy and sale relying on the content of this kind of bill of lading and the international payments usually are done based on shipping $\mathrm{B} / \mathrm{L}$.

The advantage of clean $\mathrm{B} / \mathrm{L}$ is that in relation between transport agent and consignor; it has evidences on the accuracy of its content and as previously mentioned, if the transport agent claims against the contents of $\mathrm{B} / \mathrm{L}$, he must prove it.

On the other hand, if clean $\mathrm{B} / \mathrm{L}$ is in control of goodwill third party including consignee, shipping bill of lading would be under protection of the principle of inattention to claims and principle of Estoppel and this legal evidence concerning the relation between transport agent and the third party holding bill of lading or transport document turns to definite evidence and the transport agent will be deprived of the right of proof against the inclusion against third party holder ${ }^{22}$.

\subsubsection{Unclean Bill of Lading}

Unclean bill of lading or claused bill of lading is the one including expressions indicating defect in goods or package ${ }^{23}$ or the transport agent performed reservation as will be mentioned in the next paragraph.

Concerning defaced items, unclean bill of lading neither benefits from the right of legal evidence between transport agent nor benefits from the principle of inattention to claims in case of transfer to third party since the content of this document doesn't not build trust for the holder concerning the defaced items to make the regulator support such holder: he has received defaced bill of lading and cannot claim that trusting to the content of bill of lading made him lose.

\footnotetext{
${ }^{16}$ Black's Law Dictionary. OP. Cit. P. 188

${ }^{17}$ Baatz Yvonne, Charles Debattista, Filippo Lorenzon, Andrew Serdy, Hilton Staniland and Michael Tsimplis, The Rotterdam Rules (A Practical Annotation), London, informa, 2009. P 7

${ }^{18} \mathrm{Clean} \mathrm{B} / \mathrm{L}$

${ }^{19}$ Sedeqi Neshar, A. (1997-1998). The leaflet of "Maritime Law" course, BA, Faculty of Law and Political Sciences of University of Tehran. p. 18.

${ }^{20}$ Guest A.G. Benjamin's, Sale of Good, 4th Edition, London, Sweet \& Maxwell, 1992.p. 1099

${ }^{21}$ ibid

${ }^{22}$ Moalemnia, ibid. p. 136

${ }^{23}$ Sadeqi Neshat, ibid. p. 106
} 
In Hague convention and Visby protocol and Hague-Visby regulations, clean or unclean bill of lading is not directly or indirectly mentioned and only in paragraph $3 \mathrm{c}$ of article 3, Hague convention and Hague-Visby regulation, referring to application of reservation, clean bill of lading could be extracted (using the opposite concept).

In Hamburg convention, clean or unclean bill of lading is not defined; yet, in paragraph 2 of article 17 of this convention, unconditional bill of lading is mentioned that means clean bill of lading. On the other hand, in paragraph 2 of article 16, when nothing is mentioned in bill of lading concerning the appearance of goods, it could be considered as evidence of clean bill of lading. Moreover, in paragraph 1 of article 16 on the application of reservation, it is possible to extract the concept of clean and defaced bill of lading.

In Rotterdam convention, despite the attempt of authors on its comprehensiveness, in article 1, including definitions, clean and defaced transfer documents are not defined and just in paragraph 3 of article 39 (such as paragraph 2, article 16 of Hamburg convention), no mentioning of the appearance of goods is considered as the evidence of its completeness and the concepts of clean and defaced transfer documents could be extracted from this paragraph. On the other hand, in article 40, application of reservation in transfer document is defined from which the concepts of clean and defaced bill of lading could be extracted. From article 40 and paragraph 3 of article 29 of Rotterdam convention, it could be concluded that clean and defaced transfer documents are the same as clean and defaced bill of lading are defined.

\subsection{Vessel}

\subsubsection{Legal Identity of Vessel}

Vessel is moveable property since it could be traded; thus, it could be a subject of financial right. Vessel is considered moveable property since it is designed for the purpose of moving from one place to another so that in article 42 of Iran maritime code, inspiring from civil code that mentioned in article 21, all kinds of small and big vessels, boats and baths built on river and sea and they could be moved are considered moveable property; however, since moveable property is itself divided into material, spiritual and contractual categories; vessel is considered material moveable property that according to article 19 of civil code it is considered as an object that is possible to move from one place to another without any damage to itself or its place ${ }^{24}$.

Thus, concerning above discussion and referring to articles 29, 30 and 32 of civil code, the right of vessel owner concerning vessel is material, i.e. the owner has financial right concerning the original and benefits of vessel. Thus, the legal regulations considered for moveable properties are effective for vessel; for example, if someone leaves all his moveable properties for another and vessel is among his moveable properties, his will would also include vessel. Other contracts could be applied on vessel the same way unless their implementation is subject to certain arrangement that is predicted by law.

\subsubsection{The Similarity of Vessel to Immoveable Properties and People}

The fact that vessel is moveable property and moveable property regulations governing it doesn't contradict with the nature of certain rights imaginable for it, which makes it subject to original legal system and distinguish it from other moveable properties. Among some distinguished Arab jurists, such as Mostafa Kamal Taha, relying on the common general laws governing moveable and immoveable properties, the belief is that it is possible to get the vessel ownership during a long time. By this belief, in fact, this group considers ship as immoveable property ${ }^{25}$; thus ignoring the laws and regulations explicitly expressed in maritime laws governing the ship ownership. In fact, the legal basis which this group relies on is similar to regulations of article 731 of Code of Civil Procedure and onward that in 1982 was realized as contrary to Sharia standards by guardian council. On the other hand, although vessel is considered moveable property, its personal status including registration, nationality etc. gives it real legal entity; thus, the consequences of using vessel returns to it; at the end, it could be realized as creditor, the debtor or liable the same as legal person. All these legal consequences are due to assumption of legal status by granting nationality ${ }^{26}$.

\subsubsection{Vessel Chartering Contract}

Maritime law has defined vessel chartering contract as, "the written document hold between vessel owner or his certified representative and renter determining the vessel chartering terms for certain time or several trips between

\footnotetext{
${ }^{24}$ Jafari Langroudi, M. J. (1989). Right of Property, Library of Ganje Danesh, $1^{\text {st }}$ ed., pp. 73 and 74

${ }^{25}$ Kamal Taha, M. (1982). Al-qanon Bari (Maritime Law), No. 169. P. 248

${ }^{26}$ Yari, ibid. p. 35
} 
ports" ${ }^{\prime 27}$. It is clear that vessel chartering contract or charter party gives this possibility to the owner to rent its vessel the same as other properties while keeping its ownership. The manner of transferring vessel exploitation right to other is different and requires certain condition. Concerning the significance of vessel chartering contract in maritime transport will be discussed later. What could be inferred from definition of shipping transfer contract included in Iran maritime code and international regulations and its brief analysis is that the contract held between consignor and transport agent should include shipping bill of lading or other similar documents. In other words, the contract between consignor and transport agent is considered shipping transport contract if shipping bill of lading or similar documents are issued. Thus, issuing bill of lading by transport agent at the time of receiving goods from the consignor has essential role in transport contract; so the credit and significance of shipping bill of lading should be searched in bill of lading. In addition, it should be considered that this is not unique to the relations between consignor and transport agent but it is true about the relation between consignor and consignee; especially when there is some controversy between consignor and consignee ${ }^{28}$. Due to significance of bill of lading in shipping transport, it is required to explain this issue further.

\section{Content of Shipping Bill of Lading}

Article 60 of maritime code has specified the minimum conditions that should be mentioned in bill of lading including:

1) Name of vessel

2) Name of port of loading, date of loading and name of port of discharge

3) Mark, description, type of cargo and number of packaging and total

4) Net and gross weights and volume of cargo

5) Name and address of consignor, transport agent and consignee

6) Terms of lading, transport and unit rate

7) Number of versions of bill of lading

Since the above article is not included in the referred items in article 190 on the crimes and offences, it can be concluded that failure in following article 90 at the time developing bill of lading is not considered violation and even if it is considered violation, it doesn't lead to invalidity of shipping bill of lading and thus transport contract. Thus, it could be concluded that the content of bill of lading is not confined to abovementioned items but it could be increased or decreased based on the agreement of parties. Thus, the main items of bill of lading could be studied as follow:

The name of vessel, by which the cargo is transported, should be mentioned in bill of lading according to the vessel name law. The significance of this issue is on that the consignor and consignee of cargo will be able to realize the vessel carrying the cargo and be informed of the time of its arrival and to be prepared for discharge. In bill of lading, the date of issue should be included.

In Rotterdam convention, the items included in paragraph 2, article 26 including: a. the appearance of cargo, b. the specification of transport agent, c. the date of cargo receipt or date of lading according to the date of issuing transport document.

\subsection{Freight}

An important issue in shipping transport is the status and manner of paying the freight. According to the type of sale contract in international sales, or representative contract, the freight might be paid by the consignee or consignor. This is while transport agent is unformed of the sale contract and the controversy between consignor and consignee might lead to confusion of transport agent. Moreover, it might happen that the consignee becomes obliged to pay freight and demurrage due to the right of lien by the transport agent despite the fact that according to the sale contract he has no responsibility and commitment to pay it. Thus, in paragraph $1 \mathrm{~h}$, article 15 of Hamburg convention it is mentioned that the manner of freight payment should be mentioned in shipping bill of lading and in paragraph 4 of article 16, the content of bill of lading concerning freight and demurrage is considered a legal evidence; however, if the bill of lading is transferred to a goodwill third party, proving opposite of bill of lading concerning these two items against holder of bill of lading is not reliable. This is confirmed by Hamburg convention due to the fact that the status of freight and demurrage has direct influence on the cost price of the

\footnotetext{
${ }^{27}$ Article 135, Iran maritime code

${ }^{28}$ Mohebi, M. (2010), Comparative study of the responsibility of transport agent concerning damage to goods in Hamburg and Rotterdam convention. MA thesis, Islamic Azad university, Science and Research branch. P. 89
} 
goods subject of bill of lading and concerning transferability of bill of lading, the tradesmen calculate the total value of goods according to content of bill of lading and trade it by documents.

\subsection{Vessel Name, Date of Loading and Contract's Parties}

The name of vessel, by which the cargo is transported, should be mentioned in bill of lading according to the vessel name law. The significance of this issue is on that the consignor and consignee of cargo will be able to realize the shipper vessel and be informed of the time of its arrival to be prepared for discharge.

Date of loading should be mentioned in bill of lading which is very significant since it indicates the time of delivery of goods to vessel commander. Thus, the criterion for beginning of the delegation of commander in storage of cargo, transporting and his responsibility in case of damage or delay is the time of issue.

In addition, in marine cases, it is possible to realize by this date whether the consignor has performed his commitments on delivery of cargo at the agreed time or not. According to article 63 of marine law, the bill of lading should be issued within 24 hours of loading the cargo. To this end, the bill of lading should be signed by the commander or someone assigned by $\mathrm{him}^{29}$.

According to paragraph 5, article 60 pursuant to Article 61 of marine code, the name of parties to transport and contract should be mentioned in the bill of lading. Thus, in shipping bill of lading, the name of consignor, transport agent and consignee should be mentioned; however, determining the name of consignee seems not that much necessary as mentioned in article 61. In other words, in this regard, bill of lading has three conditions as follow:

First condition: Issuance of shipping bill of lading to the odder of certain person

One condition inferred from article 61 is the one where the name of consignee will be completed in the related column in bill of lading and it is issued to the order of certain person. In this condition, bill of lading is either issued to the name of consignor or consignee in port of discharge. This bill of lading is named and its legal holder is someone whose name is included.

Second condition: Issuance of bill of lading on bearer

Sometimes, it might happen that the consignor is neither inclined to deliver the goods to the consignee name not to mention his name as consignor; thus, he agrees with the commander or transport agent to issue bill of lading on bearer's name. in this condition, the holder of document is considered owner and liable to take the goods ${ }^{30}$ and the transfer right could not be foreclosed. In case of transfer, there is no need to write anything on bill of lading, rather, transfer will be done by bills ${ }^{31}$.

Third condition: Issuance of bill of lading payable to order

Another condition considered by regulator in issuance of bill of lading is issuance of bill of lading payable to the order. In this condition, the bill of lading is issued payable to order of certain person who could transfer it to another by endorsement. In such condition, endorsement should be considered subject to trade regulations.

Thus, firstly, endorsement should be signed by endorser and secondly, the date and name of someone to which bill of lading is transferred might be included in endorsement ${ }^{32}$.

\subsection{Cargo Description and the Number of Bill of Lading}

Bill of lading is the main document for receipt of cargo and goods, thus, it should guarantee type, measure, number of package and marks of loaded goods on vessel. It is clear that in case of lose or confusion of goods, these marks and specification could help solving the problem.

In addition, bill of lading should be written at least in four versions, the first one is the main one which is issued for consignor, second version is for consignee, third version is for the commander and fourth version is for owner of vessel or his representative ${ }^{33}$. However, it is frequently seen that in practice, bill of lading is written in two versions: one is within commander of ship which is kept for transport agent and second version is given to the consignor ${ }^{34}$. I could be inferred from expression "at least" mentioned in law that the receipt of bill of lading is mostly written in more than four versions and this could be for prevention of emergence of dangers such as theft or demolishing of

\footnotetext{
${ }^{29}$ Article 62, marine code

${ }^{30}$ Article 320, Trade law

${ }^{31}$ Mohebbi, M. ibid, pp. 351-352

${ }^{32}$ Article 246 of trade law

${ }^{33}$ Artcile 62, Maritime Code

${ }^{34}$ Mohebbi, M. ibid. p. 250
} 
goods.

Iranian legislator has not referred to all dimensions of bill of lading; one of them is this question that if bill of lading is issued in several versions and in order of certain person or on bearer's name, whether it is necessary to mention this issue in all versions or not and if there is controversy between the versions of bill of lading, which version is valid and what is the task of commander in this condition. In maritime laws of most countries, in addition to responding to these questions, other items have also been considered ${ }^{35}$. For example in Switzeland maritime law it is mentioned that in case of the request of commander, the transport agent or consignor, bill of lading should be signed by the consignor ${ }^{36}$. Or if the main version is presented simultaneously by several holders, the commander will deposit the goods to official competent authority or third party. Concerning depositing goods before entrance to port of discharge, Switzerland maritime law has declared that the shipper or transport agent could deliver goods and follow new orders of consignor when all main versions of bill of lading are presented to him ${ }^{37}$. Anyway, as previously mentioned, it is required that bill of lading be signed by commander; however, in practice, representative or someone assigned for this purpose signs it. Moreover, it is required that bill of lading to be signed by the consignor and the necessity for signature of consignor is that it leads to credit of bill of lading. In cases where bill of lading lacks the sign of consignor, transport agent could allege it against consignor relying on the terms mentioned in bill of lading; however, on the condition that evidences make it clear that the consignor is informed of the terms and conditions of bill of lading and accepted it.

\section{Effect of Shipping Bill of Lading on Third Party}

Concerning above-mentioned discussion, bill of lading is fully effective on the relation between transport agent and consignor and it could be considered as a document or evidence on holding transport contract, terms and the agreed rent. In addition, the date mentioned in bill of lading especially indicates delivery of goods to transport agent under terms mentioned in bill of lading.

Here, this question is raised that whether the reality and authoritativeness of content of bill of lading concerning the relation between transport agent and consignor should be absolutely accepted or considered as relative?

Maritime law has not provided any answer to this question; however, the laws of some countries have clearly answered this question and not considered certainty of bill of loading as absolute. Thus, despite the mentioned items, it is possible to prove the claim under some condition in bill of lading ${ }^{38}$. For example, transport agent could claim that the amount of goods mentioned in bill of lading is not delivered to him. It's clear that according to general laws, to prove the opposite of what is mentioned in document in written form is just possible by presenting another written document. Thus, it's the duty of transport agent to take the responsibility of proving this claim using other documents.

The authoritativeness of bill of lading is not unique to contract parties, i.e. consignor and transport agent; rather it could be extended to other agents such as the consignee or insurance company. However, this extension should not be considered an exception to the principle of relativeness of contracts including bill of lading, rather, it means that certain goods loaded on ship have economic consequences for others; thus, despite the fact that they have not role in making regulations of contract, due to personal benefits, they are committed to perform them.

Thus, in case of any controversy between consignor and consignee due to not delivering the goods, the consignor or consignee, relying on bill of lading, could prove that he has performed his obligations toward consignee. Moreover, if the goods that are insured against maritime dangers and risks suffer from damages, the proving of any of these events is possible referring to bill of lading and relying on it; i.e. by presenting bill of lading, it becomes clear that how much of goods is damaged and how much is intact. By these explanations, it could be perceived that bill of lading is not effective on the relation between parties; rather, it could be relied on concerning other people whose name and signature is not included.

The content of bill of lading concerning the relation between transport agent and consignor is considered a prima facie evidence and the transport agent could prove the opposite of content of bill of lading and use it against the consignor according to paragraph 4 and 5 of article 3; paragraph 5 of article 4- Hague convention (and Visby-Hague Regulation); paragraph 3a of article 16; paragraph 4 of article 15- Hamburg convention and paragraphs 1 and 2 of article 17 and paragraph 2 of article 9 of this convention and paragraph a of article 41 and

\footnotetext{
${ }^{35}$ Such as articles 203-302, Lebanon maritime law

${ }^{36}$ Paragraph 2, article 116, Switzerland maritime law

${ }^{37}$ Paragraph 3, the same article

${ }^{38}$ Article 199, Lebanon maritime law, article 199 Syria maritime law, article 205 Egypt maritime law and article 115, Switzerland maritime law indicate this subject in different words
} 
article 42-Rotterdam convention.

\section{Proofing Aspect of Bill of Lading}

Concerning commercial nature of bill of lading and inclusion of abstract and partnership concepts and principle of inattention to defects relatively (not absolutely), bill of lading has relative proofing power which is special to commercial documents and law of trade and has no background in civil and civil law documents. In other words, as will be explained, it is possible to speak of relative proofing capability of content of bill of lading. ${ }^{39}$ In following, the proofing aspect of shipping bill of lading in different conventions will be studied.

\subsection{In Hague Convention}

According to paragraph 4-article 3 of Hague convention (paragraph 4- article 54 of Iran maritime code), shipping bill of lading is the reason and document of receipt of cargo with the descriptions mentioned in paragraph 3-article 3 of this convention (paragraph 3 -article 54 of Iran maritime code) including:

1) Characteristic signs of goods including serial number, manufacturing company, ...

2) The number of packages, weight and size of cargo

3) The status and appearance of the cargo

According to paragraph 5, article 3 of this convention (paragraph 5, article 54- Iran maritime code), the consignor guarantees the information given to transport agent for the purpose of issuing bill of lading concerning marks, number, value and weight of cargo. Yet, the responsibility of consignor in this regard does not lead to abdicating the transport agent against goodwill holder of bill of lading (including consignee).

On the other hand, according to paragraph 5- article 4 of Hague convention (paragraph 5 -artcile 55 of Iran maritime code), bill of lading is considered evidence concerning a. the type of goods, $b$. the value and cost of goods. The implication of bill of lading on mentioned description in the first stage is a prima facie evidence and there is the possibility of proofing the opposite of bill of lading by transport agent. In other words, bill of lading is simple "legal evidence ${ }^{40 "}$ whose opposite could be proved ${ }^{41}$; yet, concerning the items mentioned in paragraph 3-artcile 3 of Hague convention, if bill of lading is at the disposal of goodwill third party (including consignee), transport agent will be deprived of disclaiming third party even in case of proofing of unreal content of bill of lading. In other words, the content of bill of lading in these cases (appearance description, number, weight and value) will turn from appearance to definite evidence. The discrepancy between paragraph 5 -artcile 4 of convention and paragraph 5 -artcile 3 of Hague convention is that the realization of type and value of goods is not within the authority of transport agent or commander and for this reason; Visby protocol has confirmed this in paragraph f-article 2 and Visby-Hague regulation in paragraph 5f-artcile 4.

On the other hand, in Visby protocol in paragraph 1-artcile 1 (and paragraph 4-artcile 3 of Visby-Hague regulations), one sentence is added to paragraph 4-acrticle 3 of Hague convention. According to this sentence, the transport agent is deprived of the right to proof the contrary of content of bill of lading as described in paragraph 3 -artcile 3 against goodwill third party holder including consignee. The adding of this sentence to paragraph 4-artcile 3 of Hague convention made transport agent explicitly approved of proofing contrary to the content of bill of lading concerning the status and appearance of cargo; something which is ignored in paragraph 5-artcile 3 of Hague convention; instead, the judicial procedures has considered transport agent deprived of proofing the contrary of content of bill of lading in this regard.

Judge "Scroten" in Silver v. Ocean ss.Co (1930) claim believes that by transferring bill of lading to third party, the ship owner (transport agent) will lose the right to proof the contrary to the claim of perfect and impeccable goods at the time of loading while they have not been so in reality. ${ }^{42}$

In "The Peter Der Grosse" case (1875), the court realized the bill of lading unscarred and sentenced the transport agent to compensate the damage; however, in "Grant v. Norway" claim, bill of lading was not considered as definite reason against ship owner. ${ }^{43}$ In this case, according to "Jervis", the judge, the ship commander issued bill

\footnotetext{
${ }^{39}$ Such as relative cancellation in article 100 and 116 of Iran trade law (1932) and article 130 of amendment of Iran trade law approved in 1968

${ }^{40}$ Concerning the definition of "prima facie evidence" (in prima facie evidence editor in chief), 9Th Edition.2009.p639) by A. Garner, this expression is equivalence of legal evidence in Iran legal literature while in Persian translation of Hague convention, it is translated as "document" that is incomplete translation

${ }^{41}$ Molamnia, ibid. p. 183

${ }^{42}$ Seydin, ibid. p. 45

${ }^{43}$ Chorley \& Giles, Shipping Law, 8th Edition, NJJ Gaskell, Battista and RJ Swatton, G.B, 1988. P. 243
} 
of lading for the goods not loaded at all, beyond his control. The verdict in "Grant v. Norway" case caused extreme insecurity of bill of lading credit since it was on contrary to Stopple and has not supported people trusting the document prepared by transport agent.

Article 3 of England bill of lading law, approved in 1855, tried to fix the unscarred validity of shipping bill of lading; according to this article, "any bill of lading at disposal of endorsed consignee or beneficiary for fee and indicates the loaded cargo will be the definite evidence against ship commander or anyone who has signed it regardless of whether part or some of goods is not loaded"44. England judicial procedure has sentenced opposite to "Grant v. Norway" case in next cases ${ }^{45}$ including V.Guthrie \& Co (1966) Aesnoimport and Leduc \& Co. v. Ward (1888) 20 QBD 475.

In Iran law, considering the amendment in civil code concerning the reasons for proof of claim and according to paragraph5-artcile 54, it is possible to prove contrary to the content of bill of lading by other reasons in any condition $^{46}$; however, in "last part" of paragraph 5-article 54 of Iran maritime code (paragraph 5-artcile 3 of Hague convention), the proof of this just leads to limited responsibility of transport agent against the consignor; however, if bill of lading is at disposal of third party, its prove will not have any effect on the goodwill third party. ${ }^{47}$

\subsection{In Hamburg Convention}

According to paragraph 3a, article 16 of Hamburg convention, except those cases reserved by transport agent, shipping bill of lading is the reason for cargo receipt or its loading by ship according to the content of bill of lading. The implication of bill of lading on the descriptions mentioned in paragraph 1-artcile 15 of Hamburg convention is a prima facie evidence and transport agent is entitled to prove the contrary; however, according to paragraph $3 \mathrm{~b}$ of article 16 and paragraphs 1 and 2- article 17, in case of transfer of bill of lading to goodwill third party (including consignee), the content of bill of lading will turn to definite reason; i.e. the principle of inattention to defects prevents the effectiveness of proofing contrary of bill of lading against goodwill third party.

In Hamburg convention, according to paragraph 1-artcile 15, the items that should or could be mentioned in shipping bill of lading are more complete than the mentioned items in paragraph 3 -artcile 3 of Hague convention. Thus, according to paragraph $3 \mathrm{~b}$-artcile 16 of Hamburg convention, the cases that could turn to definite evidence are beyond the items mentioned in paragraph 5-artcile 3 of Hague convention and includes cases mentioned in paragraph 1-artcile 15 of this convention including date of loading, port of loading etc.

On the other hand, in Hamburg convention, nothing is mentioned concerning the proofing power of shipping bill of lading concerning the type and value of cargo. In this regard, paragraph 5- article 4 of Hague convention is included incompletely in paragraph 4-artcile 6 of Hamburg convention. In this paragraph, just a part of paragraph 5 -article 4 of Hague convention related to the possibility of agreement between transport agent and consignor for determining a price more than ceiling price is included; in this way, it is not clear that according to Hamburg convention, concerning paragraph $3 \mathrm{~b}$-article 16 of bill of lading on "type" and "value" of cargo in respect to third party, whether is considered prima facie evidence or definite reason? Judicial procedure is inclined, similar to Hague convention, to say that bill of lading in this case indicates prima facie evidence which remains the same by transferring to third party.

\subsection{In Rotterdam Convention}

In Rotterdam convention, in article 36 paragraphs 1, 2 and 3, several items that should be mentioned in transport document are included. Compared to Hague convention, Visby-Hague regulations and Hamburg convention, these paragraphs include more complete details. According to paragraph a- article 41 of Rotterdam convention, transport document indicates receipt of cargo by transport agent as mentioned in transport contract included in transport documents. The indication of transport documents on these items is a prima facie evidence (legal evidence) and the transport agent could prove contrary; however, the content of transport document, according to paragraph $\mathrm{b}$ of article 41 , is turned in two cases from prima facie evidence to definite reason as mentioned below and transport agent will be deprived of proving the contrary to the contents:

1) When a "written transport document" or a "transferrable electronic transport record" is transferred from consignor to goodwill third party.

\footnotetext{
${ }^{44}$ Colinvaux Raoul, Carver's Carriage by Sea, Vol 1, London Steven \& Sones, 1973. P. 78

${ }^{45}$ Martin Dockray. Op. Cit. P. 566

${ }^{46}$ Fakhari, A. H. (1995-1996), pamphlet of Maritime Laws course, MA, Faculty of Law of Shahid Beheshti University, p. 83

${ }^{47}$ Pournouri, M. (2004). Maritime rights in maritime court. $1^{\text {st }}$ Vol., Tehran, pp. 51-52; Moalemnia, ibid. p. 83
} 
2) When a non-transferrable "written transport document", requiring submission in return of delivering goods, is transferred to consignee.

In these two cases, concerning paragraph $b$ of article 41, all contents of transport document are in favor of goodwill third party and transport documents should be turned to definite reason. Moreover, according to paragraph carticle 41, when a "non-transferrable written transport document" or a "non-transferrable electronic transport record" (not requiring submission" is issued in favor of goodwill holder, it is considered definite reason in three following cases:

1) Specifications and descriptions referred to in paragraph 1 of Article 36 (description of goods, essential marks of goods, number of packages or pieces, or the product number, product weight) provided that the specifications and descriptions are prepared by the carrier or his agents to be inserted in transport documents. These specifications are usually prepared by the transport agent when the process of loading in container (stuffing) and the custom affairs are taken by him on behalf of the consignor. Therefore, if these specifications are declared by consignor and indicated in transfer document, they are considered prima facie in favor of holder.

2) With respect to shipping transport being done in container, majority of the maritime transports even bulk goods transport such as rocks and minerals are done by container; thus, what is essential in transportation is the characteristic features of container. These vehicles are recognizable by two features in transportation and custom and port arrangements: the type of container and the identification number written on the door or wall of any container and is unique all over the world. By the type of container, it is mean 20 feet or 40 feet, ordinary or open type and non-standard. In article 36, there is no mentioning of container; however, concerning the abovementioned explanation, it could be said that by "characteristic features required for identification of goods" mentioned in paragraph $1 \mathrm{~b}$-artcile 36 , it is meant the type and identification number of container. Anyway, in "nontransferable written transport document" and "nontransferable electronic transport record", the type and identification number of container mentioned in these documents are considered in favor of third party and goodwill holder and transport gent is deprived of the right to proof contrary against consignee.

\section{Conclusion}

Shipping bill of lading, as a valid international document and a general trade document, has the capability of dual (relative) proofing. Various dimensions are considered for proofing and retaining power of this document in legal procedure of western countries that is considered in Hague and Hamburg convention implicitly or explicitly including the capability of transferring shipping bill of lading and abstract and partnership description (relative not absolute) and the principle of inattention to defects (relative not absolute) that is due to business nature of this document and prominence of this document from other ordinary documents.

The validity and credit of "shipping bill of lading of loaded goods and clean bill of lading in international trade" made this bill of lading under extreme support of trade norms, international conventions and local regulations of countries such that the transport agent is prohibited from the right of proofing contrary to the content of this documents against goodwill holder of this shipping bill of lading. Rotterdam convention has mentioned various items in support of "written transport document" and "electronic transport record" in international level and "the proofing capability and power" of these newly-established documents. Definition of transport documents in Rotterdam convention and not inclusion of the title of bill of lading do not mean negation of shipping bill of lading. Iranian regulator could take effective steps in development of national and international transport both through joining Rotterdam convention and updating fourth chapter of maritime code using mentioned convention.

\section{References}

Abdollahi, S. (2010). Rotterdam Convention (1st ed.). Tehran, port of special areas PMO.

Chorley, \& Giles. (1988). Shipping Law (8th ed.). NJJ Gaskell, Battista and RJ Swatton, G.B, 1988. P. 243.

Fakhari A. H. (1985-1986). Pamphlets of Marine code course. MA, Faculty of Law of Shahid Beheshti University.

Hoshang, O. (1973). Maritime law (Vol. 1). Tehran, Higher School of Insurance.

Jafari Langroudi, M. J. (1989). Property rights (1st ed.). library of Ganje Danesh.

Kamal Taha, M. (1982). Al-Qanun al-Bahri, the community of al-Iskandariyah, No. 169.

Kardan, K. (2012). Rotterdam Convention. Journal of Law, Faculty of Law and Political Science, 42(1).

Mirsadeghi, A. (1997-1998). Pamphlets of maritime law course of bachelor of art, faculty of law and political 
science of university of Tehran, p. 106.

Moalemnia, A. (1999). The nature of maritime bill of lading and its role in maritime transportation. University of Tehran. (Qom Higher Education Complex).

Mohebi, M. (2010). The comparative study of responsibility of transport agent toward damage of goods in Hamburg and Rotterdam Convention. Master thesis, Islamic Azad University, Science and Research Branch, Tehran.

Najafi Asfad, M. (2009). Maritime law (Vol. 2). Tehran, SAMT.

Pournouri, M. (2004). Maritime law in maritime court (1st ed.). Tehran, Mahde Hoqoq.

Seyedin, A. (1985). Legal bill of lading and its effects. Master's thesis, University of Tehran.

Translation of Iran Tribunal Claims (The Hague). (2010). Dictionary of Legal Terms (English-Farsi) (5th ed.). Dadafrin

Yari, M. (2011). The scope of implementation of the Rotterdam Convention. International Journal of Law, (45).

Yari, M. (2012). The review of Hague 1924 regulations concerning international maritime transport and Rotterdam Convention in 2008 and its probable effect on Iran maritime code. Master's thesis, Shahid Beheshti University.

\section{Copyrights}

Copyright for this article is retained by the author(s), with first publication rights granted to the journal.

This is an open-access article distributed under the terms and conditions of the Creative Commons Attribution license (http://creativecommons.org/licenses/by/4.0/). 